\title{
In search of Richard II: Shakespeare's use of eyewitness accounts of the revolution (1399-1400)
}

Conflicting tales and the dramatic structure of the play (III.2-3)

\section{Catherine Lisak}

\section{(2) OpenEdition Journals}

\section{Electronic version}

URL: http://journals.openedition.org/shakespeare/918

DOI: 10.4000/shakespeare.918

ISSN: 2271-6424

\section{Publisher}

Société Française Shakespeare

\section{Printed version}

Date of publication: 1 November 2002

Number of pages: 95-128

\section{Electronic reference}

Catherine Lisak, «In search of Richard II: Shakespeare's use of eyewitness accounts of the revolution (1399-1400) », Actes des congrès de la Société française Shakespeare [Online], 19 | 2002, Online since 01 November 2007, connection on 30 April 2019. URL : http://journals.openedition.org/shakespeare/918 ; DOI : 10.4000/shakespeare.918 
What also causes the men to desert, according to Créton, is the rumour that the king is dead. The same note is struck in Shakespeare : «For all the Welshmen, hearing thou wert dead, / Are gone to Bolingbroke, dispers'd and fled» (III.2.73-4) But from Créton's account to Shakespeare's play, variations on the same theme have taken place. The scene toys with the order of events, sometimes reversed, repeated, merged into one, or subdivided; cause and consequence are interchanged; the rhythm, harmony and melody of the scene is therefore most original though the constitutive motives are recognizably the same as in Créton. For instance, the king's death (either rumoured or symbolical) becomes not only the cause, but also the consequence of the soldiers' flight, something Christopher Pye underlines most pertinently: «The king's transformation is unsettling because it seems to fulfil the premonition that prompted his troops' flight, and thus it amounts to being at once effect and cause of his fall» ${ }^{45}$.

Bolingbroke's mounting power brings about Richard's loss of strength, morally, physically and militarily. The news of Henry's rise provokes Richard's symbolical demise and his literal mortification as he is robbed of all sense of security. Much dramatic capital is made of the fact that Henry and his intimidating army have become, what Créton himself calls «son mortel mal» ${ }^{46}$. This is expressed, both in the French chronicle and in the play, through the king's symptomatic change of complexion (Richard's fear and dismay are exposed to the world by his «yielding to deadly pallor» ${ }^{47}$ ) as well as by the spatial imagery of his fall from a great height ( $« E t$ ce nest pas / De merueillez considere le cas / De moy qui suis chut de sy hault sy bas» ${ }^{48}$ ). These are both imageries which allow for performative effects on stage and a stylised realization of the leading character.

Aum. Comfort, my liege, why looks your grace so pale?

Rich. But now the blood of twenty thousand men

Did triumph in my face, and they are fled ;

And till so much blood thither come again,

Have I not reason to look pale and dead?

(III.2.75-9)

In Créton, it is not only Richard but Salisbury who is drained of all colour as he witnesses, powerless, the desertion of the troops : «Le conte avoit la face de someil / Descoulouree / Au roy conta sa dure destinee» ${ }^{49}$. On 
various occasions the king is said to have lost all colour as he is dismayed by his reversal of fate : «La fut le roy qui ot souuent la face / Descoulouree / En regretant sa dure destinee» (The king was there, his face often pale, as he lamented his hard fate $)^{50}$. In Shakespeare, this ritualized loss of blood is a characteristic attributed to the king alone: pain and agony are concentrated into this one character, turn figure of martyrdom. Though Peter Ure remarks that Shakespeare had already used the conventional imagery of the king who blemishes under shock (in Richard III, II.1.83 \& III.7.26), this does not exclude for as much the possibility of Shakespeare encountering the use of this imagery in Créton, and finding it dramatically appropriate and effective here. It is surely more than simple coincidence that makes the dramatist resort to this imagery of fright at precisely the same moment as the chronicler. Turning pale may generally signify abashment, humiliation, and the uncontrolled and manifest acknowledgement of one's defeat. But in this specific case, le style c'est l'homme. Discomfort and mortified pallor are the iconographic signatures of Richard's faint-heartedness, inherited from first-hand accounts.

Pallor often works hand in hand with the symbolical fall from a great height, as the earlier quotation by Créton indicates. In the 'Metrical History', the imagery of the paling face is more insistently developed than that of Richard's fall. In Shakespeare, the reverse is the case, the king's fall being a running theme and metaphor throughout these two scenes, ironically announced by Richard himself early in Act III, scene 2, as some law of gravity: «weak men must fall» (III.2.62). Though he struggles at first to keep his balance, in such lines as «Look not to the ground, / Ye favourites of a king, are we not high ? / High be our thoughts» (III.2.87-9), his thoughts soon lead him to imagine betrayed kings as corpses stretched in the bowels of the earth, their «deposed bodies to the ground» (III.2.150).

The king's «discomfort», resulting from bad news, is a running theme mentioned every other page in Créton's chronicle. It is woven in the text in conjunction with another notion, that of the king's undoing or «discomfiture». Créton regularly operates the transfer from one idea to another, and at times both meanings merge into one word: «Ainsy le roy estoit a grant martire / Ueu le mischief qui sur lui tire a tire / Uenoit a tort pour le plus desconfire» ${ }^{51}$. The first meaning of the verb is «to inflict overwhelming defeat», though in this context, its meaning comes closer to its substantive form «déconfiture», a rout, but also the mental state of a person who has lost all means to face up to his responsibilities. Hence «déconfit» (utterly discouraged and dismayed). The meaning of 
«desconfire» here overlaps with that of «déconfort» (that which drains all strength and courage) and «déconforter» (to aggrieve). Créton's structural wordplay, which commands the whole of this episode, reappears in Act III, scene 2 , though not in the shape of a pun. This time the translation from one meaning to the next is enacted and dramatized. No sooner has Richard accused Aumerle of being «discomfortable», and heard Salisbury's discomforting news, than he orders his remaining troops to be sent away, thus implementing his own discomfiture : «All souls that will be safe, fly from my side» (III.2.80). The dramatic shift from state of mind (discomfort) to state of being (discomfiture) is played out again when the king learns of York's defection. The ill news induces discomfort to the point of despair, and Richard reiterates his order that his men be dismissed : «That power I have, discharge, and let them go» (III.2.211); «Discharge my followers; let them hence away» (III.2.17). The scheme that was based on metathesis in Créton reappears here invigorated in form, becoming a true metamorphosis of the king himself. A metamorphosis the king re-enacts, until he can no longer sustain the verbal deathblows of the messages he receives. Repeated discomfort has undone him in his majesty and brought about his downfall.

As in Holinshed, his discomfiture is self-inflicted : «and all called his armie together, which was not small, licenced euerie man to depart to his home» ${ }^{52}$. In the Saint Albans chronicles, it is also said that Richard, at the news of Henry's mounting strength, gave up the will to fight, though they report that the task of sending the men away devolved onto Thomas Percy. In the Ricardian texts, as in Fabyan and Caxton, Thomas Percy is accused outright as a traitor for having dismissed the king's troops without his permission (Caxton accuses him of «unwetyng the king» ${ }^{53}$ ). In Shakespeare's play, Richard is sole actor at this point; he is given to play Percy's part, following Holinshed. But his action is tinged with cowardice and self-betrayal. In acting as he does, Richard also absolves his subjects of his allegiance (something he officially does in the documents of abdication). This is perhaps one of Shakespeare's most complex visions of Richard II. The character is very difficult to grasp at this stage. He could be interpreted as a king acting as a traitor to himself and to his army. So that the audience would look upon him with the harsh, condemning eye the French chroniclers or Fabyan perceived Percy. Then again, his decision to dismiss his men could be perceived as an act of grandeur and humanity, as the last grand gesture of a king (and in the play, his first great gesture of magnanimity, befitting a king, that he never fulfilled in the first 
two Acts when it was so urgently called for) as he takes on the burden of defeat alone and does not bring his men down with him. What this reveals is the dramatist's remarkable capacity to weave within his plot both Lancastrian and Ricardian visions of history, addressing both the audience's sympathy and antipathy for Richard.

Finally, the themes of discomfort and discomfiture combine within the complex and opaque character of Aumerle, this «discomfortable cousin» who would, ironically, twice attempt to «Comfort, my liege», the king (III.2.75 \& 85) with words of comfort that neither spare him (confire) - «remember who you are» - nor build up his moral strength (conforter) — «why looks your grace so pale ?» - but undermine, confound, and cry out the king's failings. This is a character whose stock model, Créton's Albermarle, misled the king with false assurances : that by stalling in Ireland, while he and Salisbury returned to England and assembled an army, Richard would return victorious to contemplate Henry's defeated army :

$\&$ tout viens alors / Vos ennemis verrez tous pris \& mors / Ou desconfiz

Then will you soon see your enemies captured, killed, or discomfited. ${ }^{54}$

This is the character who, in Créton, inspired accusations of treachery that recall the snake from Genesis («slily resolved upon a trick»), the mark of Cain («Accursed be the man by whom this happened») or Judas's act of treachery. This last figure of betrayal will be recast and multiplied in Act III, scene 2, and incarnated in Richard's favourites, Bushy, Green and Bagot. In effect, Richard will clumsily trip up and quibble over Scroop's report of their death, crying out «Three Judases, each one thrice worse than Judas !» (III.2.132) in what comes across as a parody of himself as a king both incompetent and easily misled. In this scene, the same themes as developed in Créton all coalesce, to be rewoven into a new plot: though Shakespeare's palette recalls the chronicler's, the pattern composed is altogether different.

At the end of Act III, scene 2, as his cousin attempts one last time to regain some final hold over him (something he was reputed to have had in Créton), as he comes to see through such words of comfort, Richard finishes by cutting him short. In so doing, he renews general suspicion over his ambiguous role as counsellor and friend : 
Aum. My liege, one word.

Rich. He does me double wrong

That wounds me with the flatteries of his tongue.

(III.2.215-6)

Exacerbated discomfort culminates into the dismissal of comfort : «of comfort no man speak» (III.2.144). All attempts to console him are received with caustic derision :

What say you now? What comfort have we now ?

By heaven, I'll hate him everlastingly

That bids me be of comfort any more.

(III.2.206-8)

The themes of comfort and discomfort, first developed in Créton, have crossed the Tudor chronicles and reached Shakespeare's play, where they are reactivated one last time, with cynicism. The joke has worn thin, and neither king nor audience can any longer be taken in by this appeal to trust which inspires mistrust. Aumerle, at this stage, has become the dangerous flatterer and unwise adviser whom the chroniclers reproached Richard for listening to : this scene is, in fact, preparing us for Aumerle's role as traitor in Act V.

In fines, it seems hard to agree with Peter Ure when he states that : "There is no need to suppose with Wilson that any of the French chroniclers influenced this scene» ${ }^{55}$. Were it only because, structurally speaking, the role of Salisbury as messenger of the troops' desertion is only otherwise found in Créton and Traïson ${ }^{56}$. Were it only because Créton is the only chronicler in which Richard is said to invoke the earth to testify to his divine authority on his return to England : «Le souuerain roy qui hault fier et loing voit / En appelle a tesmoing cy endroit» ${ }^{57}$. Were it only because certain lines from Shakespeare - i.e. «both young and old rebel» (III.2.119) - echo near-to-literally certain lines by Créton - «A luy soubzmet jeunes et anciens» ${ }^{58}$. Submission to the usurper has turned into rebellion against the king; despite the reversal (Shakespeare's line not so much stresses Henry's power as the people's betrayal), there remains a great similarity between chronicler and dramatist. Another link between the play and Créton is recognizable in Richard's reflection that kings, like all human beings, «feel want, / Taste grief, need friends» (III.2.175-6). In Créton, at this very point in the story, the need for human friendship, the 
feel of want and grief are all expressed and contained in five lines, as the king, assailed by bad news, calls out for help and advice :

A cornuay estoit tout esplorez / Et es esbahis / Disant seigneurs pour dieu de paradis / Conseillez moy cy selon vostre aduis / Car au besoing voit ly homs ses amis

... the king, who remained, downcast and miserable, at Conway. "Sirs», he said, "In God's name I beg you to advise me, for in this hour of need a man must turn to his friends. ${ }^{59}$

Lastly, there is in Créton the image of the despondent king reduced to living as a vagrant, wandering from castle to castle, sleeping rough ${ }^{60}$. It is at this point in the play that Richard declares that «nothing can we call our own but death» and invites his companions to «sit upon the ground / And tell sad stories of the death of kings» (III.2.152 \& 155-6). Richard's soliloquy undeniably recalls the traditional Tudor «Daunce and Song of Death», in which a beggar, a king and a skeleton hold hands and dance to the tune of Sickness, Death's minstrel. But what also transpires is that Créton has procured a certain infrastructure to the scene. His own account has served to lay the foundations to the main motives, themes and imageries developed in these scenes.

One may thus conclude that Shakespeare makes direct use of Créton. Traïson, whose import is more considerable in the next scene, seems a much less convincing source here, as any detectable similarity with Shakespeare's text is in fact also traceable in Créton. Though it was originally quite a separate composition from Créton's work, Traïson was re-written and went through several editions; each time passages were included wholesale from Créton. One might therefore infer that out of the two chronicles, only Créton served as a source for this scene.

Again, in Act III, scene 2, one recognizes certain structural elements that only otherwise occur in the French chroniclers. The Ricardian version of events appears in a more obvious light than in the precedent scene. To begin with, Northumberland is given as the sole ambassador sent by Henry to greet the king with a message on his behalf (III.3.31ff) The Rolls of Parliament and the Saint Albans chroniclers both stated that Northumberland was accompanied by the Archbishop of Arundel. On the contrary, Traïson, Créton and the later chronicler, Hardyng (the most favourable to Richard amongst Yorkist chroniclers) all follow the same 
line and claim Northumberland went to treat with the king by himself. In an annotated remark to Traïson, Benjamin William is most revealing :

It is worthy of particular notice that the testimony of two foreign and independent chroniclers contradict the statement in Richard's resignation, as recorded in the Rolls of Parliament, that he had promised the Archbishop of Canterbury to resign the crown at Conway in Wales, being then at liberty ; and if the fact of Northumberland alone having an interview with Richard at Conway be established, as I think it is, that document is at once branded with fabrication.

(Vide Rot. Parl., iii. 416) ${ }^{61}$

The choice to make Northumberland greet the king alone links the scene in this play to those chroniclers that sympathized with Richard. A choice facilitated by the fact that Holinshed remained elliptical over this detail, so that the play does not openly go against the official Tudor version of this incident.

Another structural component, this time found directly in Holinshed, though the event is initially recounted both by the monk of Evesham and Créton, is the fact that Henry is said to have honoured the king three times, bending low, during their amiable conference. Richard would then have asked the duke to rise up from his kneeling position, extending him a courteous welcome. Holinshed, who seems to offer a literal rewriting of Evesham's passage, says : «Foorthwith, as the duke got sight of the king, he shewed a reuerend dutie as became him, in bowing his knee, and, coming forward, did so likewise the second and third time...» ${ }^{62}$. In Créton, this ternary structure is also apparent. The thrice repeated genuflexion and mark of courtesy actually structures the myth of Henry's encounter with Richard :

Then they made them king, who had dined in the keep, come down to meet Duke Henry, who as soon as he perceived him in the distance, bowed very low to the ground; as they came closer to each other he bowed a second time, with his cap in hand; and there the king took off his hood and spoke first, as follows : «Fair cousin of Lancaster, 
you are right welcome.» To which the Duke Henry

replied, bowing very low to the ground, ... ${ }^{63}$

In Act III, scene 2, Henry only actually «kneels down» once when he greets Richard. But the genuflexion is re-enacted a second and third time in Richard's own words of welcome as he invites him to get back up :

Rich. Fair cousin, you debase your princely knee

To make the base earth proud with kissing it.

$$
\text { [...] }
$$

Up, cousin, up ; your heart is up, I know,

Thus high at least, although your knee be low.

(III.3.195-6)

The ternary pattern of courtesy continues to be developed, as Bolingbroke pronounces three times his reverent respect to the king, stating his devotion and denying all ambitious intent : «My gracious lord» (III.3.189); «My gracious lord, I come but for mine own» (III.3.196) ; «So far be mine, my most redoubted lord, / As my true service shall deserve your love» (III.3.198)

Moreover, this triple mark of courtesy has been prepared long in advance in the scene, as in Créton, commanding the structural unity of the whole episode that followed in anticipation of the meeting. Firstly, in the French chronicler, the archbishop of Canterbury advises Henry to go make promises to the king and humbly beg his pardon : «Et luy curvez tres humblement mercies». Then, Northumberland informs Richard of Henry's intentions : «Et il veina a mercy deuant uous / Tres humblement a terre les genouls». Finally, Henry's attendant, the archbishop, entering the castle, is said to greet him most respectfully, by kneeling on the ground.

In Shakespeare, a very similar pattern appears. First, Henry's «stooping duty» is played out in the message he entrusts Northumberland with ; to tell Richard that

\section{Henry Bolingbroke}

On both his knees doth kiss King Richard's hand, And send allegiance and true faith of heart To his most royal person ; 
This is replayed as Northumberland delivers the message to Richard. Henry marks his respect a second time through reported speech : «Thy thrice noble cousin, / Harry Bolingbroke, doth humbly kiss thy hand» (III.3.103-4). And Northumberland pursues :

His coming hither hath no further scope Than for his lineal royalties, and to beg Infranchisement immediate on his knees

(III.3.112-4)

The third mark of respect is given a twist, for Henry's attendant does not kneel to the ground, as in Créton, perhaps because the attendant in question is the irreverent and «too brief» Northumberland, whom, in Créton, the king rebukes and who, again in Créton, betrays the king (his image has been clearly blackened in the play, when one compares Shakespeare's portrayal of the emissary with Holinshed's; he is a dark horse much closer to the character Créton depicts). His lack of respect in part breaks the ternary pattern of kneeling though it underlines it as well. It is not made to pass unnoticed in the play :

Rich. [to North.] We are amaz'd, and thus long have we stood

To watch the fearful bending of thy knee,

Because we thought ourself thy lawful king ;

And if we be, how dare thy joints forget

To pay their awful duty to our presence?

(III.3.72-6)

Henry's rise parallels Richard's fall, which has now become a mythological and architectural reality staged with the descent from the Tower to the court, like Phaeton. This descent is evoked in Holinshed («into the vtter ward»), in Froissart («downe into the courte») and in Traïson («le Roy descendi du donion en la basse court») ${ }^{64}$. The dramatic situation and setting are exploited to the full. «The English of Shakespeare seems a direct echo of the French of the old chronicler», comments J. D. Wilson ${ }^{65}$, which Peter Ure disputes, though he gives no actual reason as to why the link between both texts would be improbable. The French meaning of «basse court» - both the annexe court (as opposed to the main court), and the place where poultry and small farm animals were kept - all help to enhance the idea of Richard's debasement, loss of majesty 
and humiliation, and contribute to give a fuller meaning to Shakespeare's pun : «In the base court ? Base court, where kings grow base» (III.3.180).

There is yet another structural element in this episode that recalls certain contemporary accounts of Richard's downfall. In Shakespeare, Henry has Northumberland report that he is

hither come

Even at his feet to lay my arms and power, Provided that my banishment repeal'd And lands restor'd again be freely granted ; If not, I'll use the advantage of my power And lay the summer's dust with showers of blood Rain'd from the wounds of slaughtered Englishmen -

(III.3.38-44)

Shakespeare's vision of Bolingbroke is not entirely grounded within the Lancastrian version, according to which the duke approached the king in wholly reassuring fashion. With all his apparent good faith, his request is heavily tinged with threatening undertones. The spectator cannot feel comfortable about this display of reverence because added to it is the minatory alternative of civil war. The bloodshed of the innocent looms behind these placating, ceremonious words. In Traïson, it is reported that once he had reached Flint, Henry displayed his «intimidating army» ${ }^{66}$. In Créton, Henry is said to have commanded Northumberland to go to the king and not to come back

jusques a tant que par paix ou butin / Le roy amaine until he bring back the king «by truce of by force» ${ }^{67}$

The same expression is used in Froissart («by force or otherwise, dead or alive», see quotation page 10). Another French contemporary chronicler, the monk of Saint-Denys, who usually follows Traïson (and only occasionally Créton), goes one step further, by turning Henry into a Judas figure who approached the king at Flint «with feigned respect and the kiss of a traitor». He later recounts that the duke forgot his promise of fidelity and listened to his own ambition ${ }^{68}$. Shakespeare's lines clearly follow the French chroniclers on this point, making Henry into an ambiguous figure, whose defiance is as deadly as his show of civility is propitious. 
Richard answers by his readiness to meet his demands, which, he says : «Shall be accomplished without contradiction» (III.3.124). This is the exact same wording as in the monk of Evesham. In effect, when recalling how courteously Henry approached the king, asking only for his due, not his kingdom, the monk of Evesham has Richard answer : «For this indeed I am prepared, and you may have all your possessions in peace without contradiction» ${ }^{69}$. The same idea recurs in Créton, who makes Richard chime in : "If it pleases you, fair cousin, it pleases us as well'. These, I assure you, are the very words that they exchanged, no more and no less...» ${ }^{70}$. «Fair cousin», again, echoes in Shakespeare's line as Richard greets Henry (III.3.190). And in Shakespeare, Richard submits, likewise, in mimetic fashion: "What you will have, I'll give, and willing too» (III.3.206).

This, of course, leads us to the question of enforced deposition versus voluntary abdication. Richard's apparent willingness to give up his title trembles in the balance in the following lines:

For do we must what force will have us do.

Set on towards London, cousin, is it so ?

Bol. Yea, my good lord.

Rich. Then I must not say no.

(III.3.207-9)

Richard is quick to add a sense of compulsion - «must», «force», «have do», «is it so ?», «must not say no» - to his avowed acquiescence. This equivocal answer is in keeping with those Lancastrian chroniclers who did not support the version of a voluntary promise of resignation but, like the monk of Evesham, doubted the king submitted without constraint. Adam of Usk was adamant about his being forced into abdication. The author of the Continuatio Eulogii considered Richard was left with no choice, whilst Capgrave could see no initiative on the king's part. The same ambivalence is expressed in the French chronicles, but with a difference : they portray Richard as a betrayed man, trapped into abdicating. His attempt to revolt evolves into a Christ-like resignation to his fate. In the play, Richard seems torn between submission and revolt. However willing he may seem, he performs his abdication as a sacrificial act of enforced self-destruction, and his face wears both the masks of smiles and tears.

Rich. What must the king do now ? Must he submit ? 
The king shall do it. Must he be depos'd ?

The king shall be contented. Must he lose

The name of king ? a God's name, let it go.

(III.3.143-6)

His attitude has been ambivalent since his return from Ireland : «Needs must I like it well : I weep for joy» (III.2.4). It takes the shape of radical mood-swings, his unstable humour passing in oxymoronic fashion from euphoria to despair, from cries to cheers. He compares himself to a mother with her young who «Plays fondly with her tears and smiles in meeting, / So weeping, smiling, greet I thee, my earth» (III.2.9-10). These contrasting tempers characterize Richard throughout these scenes, as we watch him alternate from over-confidence to bewilderment and helpless grief. He is portrayed similarly in the French chronicles, where he often passes from being piteously grieved to feeling wrath and righteous indignation, cursing and wishing vengeance upon all traitors. When he would be tempted to defy the enemy and die in battle, Aumerle advises him to «fight with gentle words» (III.3.131), a form of submission by way of diplomacy which Richard adopts with an agonizing sense of humiliation. These contradictions make up the character throughout these two scenes, as in the French chroniclers, in which they constitute a structural pattern that commands the tone of the texts.

Finally, the figure of the weeping king in both scene 2 («with rainy eyes», III.2.146) and scene 3 («Sorrow and grief of heart», III.3.184) can also be traced back to Créton and Traïson. Peter Ure remarks in note that : «His melancholy and despair are immensely expanded and vivified from Holinshed's account». And in a comment on the tirades of lamentation that appear in these scenes, J. D. Wilson shows that :

The play's chief debt to Le Beau or Traïson is in the conception of Richard's character after his downfall. I have said above that the germs of that character may all be traced to hints in Holinshed. The despairing speeches and soliloquies in Shakespeare may have, however, remarkable parallels in the lengthy lamentations which the French writer places in the King's mouth, so remarkable that it is difficult to believe there is no connexion between them. ${ }^{71}$ 
Traïson, especially, describes the king as weeping in company of his attendants. Taken prisoner by Northumberland, the king and his men «with tears and lamentations, [they] came to Flint» ; seeing Henry's army, «Then began king Richard to tremble and to weep, as well as his companions»; and again, "turning to his friends, who were all weeping...» ${ }^{72}$. This ritualized, ceremonious grief, in which the king is not alone to shed tears of despair, crosses Act III, scene 3, in shape of a litany : «We'll make foul weather with despised tears» (III.3.161) ; «And make some pretty match with shedding tears ?» (III:3.165) «Two kinsmen digg'd their graves with weeping eyes !» (III.3.169).

Créton's evocation of the king's and king's men's tears and pain is also ritualized, though it takes on a more intimate tone. He makes the king describe his own sufferance :

\begin{abstract}
«Dedans mon cuer tant de douleur recueil / Et de greuance / Que souuent suis près de desesperance»; [...] «Ainsy disoit le roy plorant des yeulx / Piteusement car il ne pouoit mieulx / En ces temps la». ${ }^{73}$
\end{abstract}

Or else it is the chronicler himself who evokes the pain that such a spectacle provoked in him: thus, he explains that when looking at the king, he «Plus de cent fois en gettay mainte larme», and recounts how the king often spoke «En souspirant du cuer piteusement».

Shakespeare will also have his king describe his own feelings of pain, and he comes close to the French chroniclers at this point, though the effect produced is quite the opposite : high drama and excess of emotions do not gain our sympathy; on the contrary, they make us replace pity with contempt and disregard. What served to command the reader's imaginative sympathy in Créton and Trä̈son becomes a repugnant slant to his character in the play. Shakespeare hardly exonerates the king from charges of weakness and ineptness. In a note to Act III, scene 3, J. D. Wilson quotes Herford : «Shakespeare, firmly impartial as ever, takes equal pains to show us Richard's fatuity and to prevent our despising him for it» ${ }^{74}$. It could be said, on the contrary, that Shakespeare does not in the least seek to preserve our sympathy at all costs. Similarly, Henry's guilt as a usurper will not be wiped clean : he will be shown for the calculating gentle noble who stabs in the back. The Machiavellian politician is as difficult to condone as the Christian martyr. Neither Lancastrian nor Ricardian versions are given the last word. Richard's quiddity, so irritating both to 
his companions and to the audience, can sometimes turn into undignified cries of complaint that touch us because they come across as so terribly human and moving. Shakespeare's Richard is received not so much as a second Christ (unless in parodied form) as a plain pedestrian human being awoken to his frailties and shortcomings, though he wears the crown yet, even if for a very little while.

This interpretation of Shakespeare's handling of French chronicles would hope to counterbalance Peter Ure's perhaps too severe refutation of the French connection :

The deepening atmosphere of shock in the last two Acts, the pity for Richard that his abasement induces in himself and his audience, thus have a family resemblance to the consternation and pity aroused by the whole affair which finds expression in the pages of Traïson and Créton. But to suggest that the one is the cause of the other is a conjecture which is not supported by those evidences of verbal correspondence between the three accounts which, in similar cases of doubt, can carry conviction. ${ }^{75}$

Behind superficial similarities, nuances of phrase have led certain critics to invalidate all links between Shakespeare's Richard II and the French contemporary chroniclers as specious. But in identifying these apparently shoaly echoes, it has come to light in this study that the play often reiterates certain structural elements found in first-hand accounts, investing them with new symbolic meaning, and at times even reverse effects. This ironical processing of schemes and patterns as apparent in contemporary texts sharply sets off the awkwardness of both Ricardian and Lancastrian bigoted assumptions. The play harmonizes opposing partisan accounts, subsuming disparity into similarity. J.D. Wilson had clearly understood this when he wrote that: «Shakespeare's genius succeeded in fusing these originally contradictory conceptions and in composing therefrom a figure of a king who seems to us as one of the most living of his characters» ${ }^{76}$. Both scenes 2 and 3 of Act III reveal to what extent the dramatist explores semiotic, dramatic and structural components of past chronicles, for the emotional intensity they contain and the vivid stage presence they procure his characters, but mostly for the 
mythical quality they bring out in the story of Richard's portentous downfall, making history live on, beyond the event. The use of such sources serves to inscribe highly imaginative scenes within a historical basis ; historical, not because it necessarily aims at offering the ultimate truth, but because it recognizes and seizes upon the mystique transmitted from chronicler to chronicler, from poet to dramatist, thus constructing a story or history within an immortalized framework. Shakespeare's genius consists perhaps in having recognized and worked on these imaginative constructs, which could purport events of the past and safeguard them within the national heritage from withering into oblivion - or downright indifference.

Catherine LIS A K Université de Bordeaux III

\section{N O T E S}

${ }^{1}$ Adam of Usk, Chronicon Adae de Usk, edited with an English translation by Edward Maunde Thompson, 2d ed., London, H. Frowde, 1904. Adam of Usk joined Bolingbroke's forces and accompanied the duke on his march to Cheshire. Whereupon he returned to London, where he was appointed to the committee set up by Henry to determine «the matter of setting aside Richard, and of choosing Henry, Duke of Lancaster in stead».

${ }^{2}$ Monk of Evesham, Historia Vitae et Regni Ricardi Secundi, ed. and introd. by George B. Stow, Jr., USA, University of Pennsylvania Press, 1977. The Vitae is now considered by historians as a largely independent source and as such, as a text of great historical value.

${ }^{3}$ Sire Jean Froissart, The Chronicle of Froissart, transl. By John Bourchier, Lord Berners, ed. G. C. Macaulay, London, Macmillan, 1924.

${ }^{4}$ Traïson exists in several editions. This article will refer to Benjamin William's edition, London, The English Historical Society, 1846.

${ }^{5}$ The edition most referred to is Histoire du roy d'Angleterre [1I], introd. and transl. by Rev. John Webb, Archaeologia, XX, 1824, p. 1-423. But unless otherwise specified, the references in this article will be to the manuscript of the 
1758 edition (MS 598), from Charles Adrien Picard's library, locatable at Lambeth Palace.

${ }^{6}$ Paul Reyher, Notes sur les Sources de 'Richard II', Librairie Henri Didier, Paris, 1924. Though J. D. Wilson remarked in his introduction that «the links, which Professor Reyher [of Nancy] notes between Richard II and Traïson are not at first sight overwhelming, and leave it open to question whether the coincidences might not be explained by reference to other sources», he acknowledges that «I, together with all future editors of Richard II, rest deeply in his debt» (introd. p. xlvii).

${ }^{7}$ John Dover Wilson, ed., Richard II, Cambridge, at the University Press, 1939, introd. p. Iviii-lix.

${ }^{8}$ Chronicon Adae de Usk, p. 43.

${ }^{9}$ J. D. Wilson, introd. p. lxi.

${ }^{10}$ Ivor John, ed., Richard II, London, Arden, 1912, introd. p. xi.

"Peter Ure, «Shakespeare's Play and the French Sources of Holinshed's and Stow's account of Richard II», Notes and Queries, October, 1953, p. 426.

${ }^{12}$ Chronicles of the Revolution, 1397-1400, The Reign of Richard 11, transl. and ed. by Chris Given-Wilson, Manchester Medieval Sources Series, Manchester \& New York, Manchester UP, 1993, p. 8.

${ }^{13}$ Hol. iii. 497/1 marg. John Dee's text is locatable at Lambeth Palace. It bears his signature and is dated 1575 . Other marginal references to this text are Hol. iii. 499/1 («Out of Dees Frenche booke») and Hol. iii. 500/1 («Out of master Dees booke»).

${ }^{14}$ Hol. iii. 488/2/marg. («The French Pamphlet. Iohn Stow. Fabian»). See P. Ure, in $N \& Q$, p. 27, who gives extant details on these marginal references. Traïson is, indeed, among Stow's papers in the Harleian Library at the British Museum.

${ }^{15}$ P. Ure, $N \& Q$, p. 426-7 and 428-9.

${ }^{16}$ Henry Neill Paul, The Royal Play of Macbeth, Macmillan, New York, 1951 , p. 201, quoted in P. Ure, ed., King Richard II, Arden, 2d ed., London \& New York, Methuen, 1956, introd. p. xxxi.

${ }^{17} \mathrm{P}$. Ure, introd. p. $\mathrm{xxx}$.

${ }^{18}$ P. Ure, introd. p. xlvi.

${ }^{19}$ Gerald U. de Sousa, «The Semiotics of Kingship in Richard II», in Shakespeare and Deconstruction, eds. G. Douglas Atkins and David M. Bergeron, Peter Lang, New York, 1988, p. 185.

${ }^{20}$ Henry Ansgar Kelly, Divine Providence in the England of Shakespeare's Histories, Harvard University Press, Cambridge, Massachusetts, 1970, p. 111-2.

${ }^{21} \mathrm{R}$. Doleman, A Conference about the Next Succession to the Crowne of Inglande, 1594, Part 2, Cap IIII : «The Great and General controvesie and contention betweene the two houses royal of Lancaster and York...», p. 56-7.

${ }^{22}$ See George B. Stow, «Richard II in Thomas Walsingham's Chronicles», Speculum 59/1, 1984, 68-102. 
${ }^{23}$ Jean Créton was «present with Richard, whom he much admired, on his expedition to Ireland in 1399, and is a first-rate witness for the year of his fall», C. Oman, The History of England. From the accession of Richard II. to the death of Richard III. (1377-1485), Longman, New York \& London, 1906, p. 499, as quoted in J. D. Wilson's introd. p. xlvi.

${ }^{24}$ Quoted in Charles L. Kingsford, Prejudice and Promise in XVth Century England. The Ford Lectures, 1923-24, Clarendon Press, Oxford, 1925, p. 3-4.

${ }^{25}$ Bruce R. Smith, Shakespeare and Masculinity, Oxford Shakespeare Topics, Oxford, OUP, 2000, «Ideals», p. 46-7. 1599, p. 85.

${ }^{26}$ John Hayward, The First Part of the Life and Raigne of King Henrie IIII,

${ }^{27} \mathrm{P}$. Ure, introd. p. 1xii.

${ }^{28}$ Bruce R. Smith, p. 133.

${ }^{29}$ A. L. French, «Who Deposed Richard the Second ?» Essays in Criticism, 17,1967, p. $429 \& 431$.

${ }^{30}$ Hol. iii. 499/1/17.

${ }^{31}$ J. D. Wilson, notes, p. 183.

${ }^{32}$ Hol. iii. 499/2.

${ }^{33}$ J. D. Wilson, notes, p. 182.

${ }^{34}$ Historia Vitae, p. 151 and 155. J. D. Wilson remarks (note, p. 183): «Barclowlie castle is a copyist's or printer's error for Hertlowli, which in turn is the form given to Harddlech (mod. Harlech) by the monk of Evesham in his Life of Richard II». L. D. Duls explains the monk of Evesham's reasoning in locating the action at Flint : «It seems highly improbable that this meeting took place at Conway. Why would Henry arrange for Richard to be taken from Flint back to the coast at Conway, where escape to France was relatively easy ? Perhaps the monk of Evesham doubted whether the king submitted at Conway without compulsion, as the Saint Albans writers said, and therefore reconstructed the story in what seemed to him a more likely fashion, indicating that Richard was intimidated at Conway by Henry's large army» (p. 126, n. 33).

${ }^{35}$ Louisa Desaussure Duls, Richard II in the Early Chronicles, Mouton, The Hague, Paris, 1975, p. 144-5.

${ }^{36} \mathrm{~J}$. D. Wilson, notes p. 189.

${ }^{37}$ Quoted in Benjamin Williams, p. 189, n. 1. Thomas Otterbourne, Chronica Regum Angliae, vol. 1 of Duo Rerum Anglicarum Scriptores Veteres, ed. by Thomas Hearne, Oxford, 1732.

${ }^{38}$ Robert Fabyan, The New Chronicles of England and France in Two Parts, Named by Himself The Concordance of Histories, reprinted by Pynson's edition of 1516, ed. by Henry Ellis, London, 1811. L. D. Duls thus summarizes Fabyan, p.150 : «Having landed at Milford Haven, in the beginning of September (sic), Richard went to Flint Castle in Wales and waited there to gather more men», William Caxton, Continuation of the Polychronicon, Polychronicon Ranulphi 
Higden, monachi cestrensis, together with an English translation of John Trevisa and of an Unknown Writer of the Fifteenth Century, ed. Rev. Joseph Rawson Lumby, Rolls Series, London, 1882, VIII, p. 539.

${ }^{39}$ L. D. Duls, p. 150 \& 154.

${ }^{40}$ Richmond Noble, Shakespeare's Biblical Knowledge and Use of the Book of Common Prayer, as exemplified in the plays of the first folio, London, Macmillan, 1935, p. $63 \& 154$.

${ }^{41}$ Hol. iii. 499/3.

${ }^{42}$ Hall, «An introduccion into the History of Kyng Henry», p. 8.

${ }^{43}$ Créton, p. 29.

${ }^{44}$ Créton, p. 18 ; C. Given-Wilson, p. 139.

${ }^{45}$ Christopher Pye, «The Betrayal of the Gaze : Theatricality and Power in Shakespeare's Richard II» ELH, 55, 3, Fall, 1988, p. 593.

${ }^{46}$ Créton, p. 22.

${ }^{47}$ Harding Craig, ed., Richard II, 1912, note on 2.1.118 as quoted by J. D. Wilson, introd. p. Ixi. «Another seeming link between the play and contemporary accounts of the persons it deals with is to be found in the stress laid upon Richard's complexion».

${ }^{48}$ Créton, p. 32.

${ }^{49}$ Créton, p. 21.

${ }^{50}$ Créton, p. 31 ; C. Given-Wilson, p. 142.

${ }^{51}$ Créton, p. 39.

${ }^{52}$ Hol. iii. 499/3.

${ }^{53}$ Saint Albans, see Duls, p. 119 ; Caxton, Higden's Polychronicon, VIII, p. 538-539 ; Fabyan, see Duls, p. 151.

${ }^{54}$ Créton, p. 15 ; C. Given-Wilson, p. 138.

${ }^{55}$ P. Ure, notes [Material], p. 94.

${ }^{56}$ Traïson, p. 190-1.

${ }^{57}$ Créton, p. 23.

${ }^{58}$ Créton, p. 15.

${ }^{59}$ Créton, p. 25 ; C. Given-Wilson, p. 141.

${ }^{60}$ Créton, p. 32. Créton exclaims : «La grant misere certes dire je nose / Que le roy ot [...] / Considere / Le mal quil at et la grant misere...».

${ }^{61}$ Traïson, p. $193:$ «... the earl of Northumberland, whom I have sent to him to effect a reconciliation between us...»; p. 195 ; «the Duke sent to King Richard the Earl of Northumberland, who was aged, that the king might rather believe his words, and not be so overbearing with him as with a younger person»; Créton, p. 37 : «le duc henry dist lors tres bel et bien / Fera le fait et sera bon moyen / Northonberlant le conte ancien / Mon beau cousin / Je lo quil parte demain au plus matin»; C. Given-Wilson, p. 144 : «it is my advice that the aged duke of Northumberland, my fair cousin, should set out tomorrow early in the morning».

${ }^{62}$ Hol. iii. 501, who follows Evesham, p. 155. 
${ }^{63}$ C. Given-Wilson, p. 149-150. See Créton, p. 37, 41 \& 43.

${ }^{64}$ Hol. iii. 501/2/ 8 ; Froissart, vi, p. 368 ; Traïson, p. 59.

${ }^{65} \mathrm{~J}$. D. Wilson, introd. p. lix.

${ }^{66}$ Traïson, p. 207.

${ }^{67}$ Créton, p. 37 ; C. Given-Wilson, p. 144.

${ }^{68}$ Chronique du religieux de Saint-Denys, contenant le règne de Charles VI, de 1380 à 1422, transl. [from Latin into French] by M. L. Bellaquet, Paris, 183940, vol. II, p. $708 \& 712$.

${ }^{69}$ Evesham, p. 155.

${ }^{70}$ C. Given-Wilson, p. 150.

${ }^{71} \mathrm{~J}$. D. Wilson, introd. p. lviii.

${ }^{72}$ Traison, p. 201.

${ }^{73}$ Créton, p. 32 \& 33.

${ }^{74}$ J. D. Wilson, notes, p. 193.

${ }^{75} \mathrm{P}$. Ure, introd. p. xlvii.

${ }^{76} \mathrm{~J}$. D. Wilson, introd. p. lix. 